\title{
A Study on the Ideology of the Cultural and Creative Talents in Response to the Global Development ${ }^{*}$
}

\author{
Huishu Zhang \\ Department of Engineering and Art, Beijing Union University, Fatou, Chaoyang District, Beijing, China \\ Huishu Zhang Studio, Beijing Union University, Fatou, Chaoyang District, Beijing, China \\ jdthuishu@126.com,shthuishu@buu.edu.cn
}

\begin{abstract}
Globalization has had a tremendous impact on the national economy, politics and culture, and it also brought about many problems, such as beliefs, cultural security, and adverse effects etc.. This paper analyses factors of creative talents in the national development in response to the global development. The paper also discusses various factors that influence values of creative talents, including economic, talents' and cultural globalization, and international relations and domestic politics. Such values possessed by creative talents as consumerism, individualism, freedom, equity, multi-direction, patriotism, ecologism and frugality are also dealt with. It argues that the cultural and creative talents should have the mainstream values and provide a reference for the purpose of promoting the development and reform of the country.
\end{abstract}

Index Terms - Globalization, Cultural and Creative talents, ideology, values

\section{Introduction}

With the rapid development of the world, the emergence of workflow, outsourcing, offshore operations, open sources, insourcing, global supply chain etc[1]. Human beings will invest more and more time in the field of business activities[2], and economy, politics, culture, talent, innovation will go more global. Talents on the one hand have more equal opportunities to compete and cooperate with people from all over the world. On the other hand, the talents are also more and more challenged by the technology. When science and technology are developed to a certain stage, these will limit the freedom of talents, and thus prevent the development, thinking and creation of talents. With this double-edged sword, significant changes took place in the demand for talents, their life style, and ideology and so on. Cultural and creative talents, as the most creative human resources, are responsible for the dissemination of national thoughts. Because ideology serves the interest and strategy of the country, the ideology of creative talents becomes increasingly important. How is local culture going to face the foreign culture[3]? How to shield the adverse impact and how to a new culture and values along with the development of the times? How to promote social security? Today, how to guide people to share their creative life and get back the lost spirit? How to guide a large number of farmers to integrate into the city's urban civilization? These problems need to be solved urgently, thus we need cultural and creative talents, and the construction of such a team must first of all consider the ideology of cultural and creative talents.

\section{The role and characteristics of creative talents}

A. The role of creative talents

Marxists believe that man is the most active factor in the productive forces. Head of Creative Industries of United Nations Conference on Trade and Development, Mr. Santos proposed that what matters most for the development of cultural and creative industries is talent quality; former U.S. Assistant Secretary of Defense Neel put forward the concept of soft power, including comprehensive ideology; the economist David S Landes in his Dynasties: Fortunes and Misfortunes of the World's Great Family Businesses pointed out that the key to the leap of a country lies in different cultural endowment, in particular values. In developing countries cultural and creative industries has a relatively short history, and cultural and creative talents cannot meet the needs of new tasks and new requirements in the national development. There are many problems in the field of creative talents development, such as the talent's ideology, quality, quantity, structure, innovation, incentive mechanism, brain drain, policy and system, the use of talent, talent development environment, talent training, talent internationalization and safety. Creative talents with good ideology not only can make the economy grow rapidly, healthily and sustainably, avoid adverse effects brought about by cultural globalization and the development of science and technology, but also can create the cultural products with higher quality, educate and guide people to obey the social mainstream values, to play a greater role in promoting national and social development. Meanwhile it will help cultural and creative talents improve their scalability, efficiency, initiative, quality, national identity and better the environment for talents. The cultural and creative talents will provide better service voluntarily for the country in the atmosphere of equality and freedom, which will enable effective implementation of the national strategy and solution of the problem so as to enhance the competitiveness of the economy, politics, culture, national defense and sustainable development in the global development.

\section{B. The characteristics of the creative talents}

Cultural creative talents need to have a more extensive knowledge in natural sciences, humanities and social Sciences, and they are highly sensitive in the new things and cuttingedge knowledge with a keen observation. They can apply

\footnotetext{
* This work is partially supported by Huishu Zhang Studio.
} 
natural science and technology and social sciences to the production of cultural products and ideas[4]. Creative talents can get a strong sense of belonging in a constant achievements, may have strong moral quality, such as good faith, extraordinary courage, stronger thinking ability and creativity, perseverance and diligence.

\section{Ideology, values and culture}

A. Ideology

1) Definition

Definition of Ideology on Wikipedia. An ideology is a set of ideas proposed by the dominant class of society to all members of society. It can be a set of cultural beliefs which a certain class, group, or other social parts use in their struggles for the privilege and domination over the other groups in order to legalize or justify their interest or to provide strategies to help them get more interests, which is becoming an increasingly important part of power, and provides the internal cohesion. In the new development stage of the society, the author believes that the new ideology is helpful to unify people's thinking, maintain social stability and resolve various social contradictions. An ideology formed according to the current social development and social problems, not the ideology that people naturally formed, may be good, but also be bad must be controlled. The new ideology needs the talents to spread and permeate.

2) The classification of ideology

Ideology is an ideological system reflecting social economic form and political system, including the mainstream and non-mainstream ideology, different levels of ideology, different forms of ideology (such as philosophy, politics, law, religion, art, etc.), and various social trends of thought. The core of ideology is the values of the ruling class, influencing people's political life, referring to social power relations.

\section{B. Values}

Values in many fields have given forms, such as social values, personal values, economic values, legal value, and so on. Values refer to the total evaluation and general opinion of a person on the objective things (including people, things and objects). On the one hand, it is mainly represented by value orientation, value pursuit with a certain value target as its final form; on the other hand, it is represented by the value criterion, which is the standard for people to judge values of matters[5].

The values are the internal power that drives people's to behave in a certain way, and it is cultivated through the social culture. Family, school, media, etc., play a key role in the formation of individual values, and other social environment also has important influence. Value determines the self cognition, directly influence and decides the direction of a person's ideal, belief, life goal and pursuit. Creative talents with active thinking, engaging in more creative activities, therefore need to have open space and to express ideas freely, and to communicate and exchange ideas, which cannot be limited by scientific and technological means. Their sense of achievement needs to be enhanced, recognized and respected so as to strengthen their sense of belonging, so that they can be active, full of responsibility and pleasure in the development of cultural and creative industries.

\section{Ideology, values and culture}

Cultural characteristics are influenced and restricted by the national economic development and social environment. It is the spiritual expression of social production modes and life style. The ideology and culture of the ruling class are basically the mainstream culture of the society, which plays a great role in the political and economic development.

Due to its role of communicator, the ideology of creative talents should accord with the interests of the country and guide the mass to promote the development and stability of the country. But the cognition and demand of creative talents are often influenced by social environment and education. Therefore good social environment and education can promote the society to enter a virtuous circle.

\section{The analysis of the factors influencing values of the creative talents to deal with the global development}

\section{A. The impact of globalization on the value of creative talents}

Globalization and information technology are changing people's life style and ideas.

1) The influence of economic globalization on the values of the creative talents

The development and characteristics of each country's cultural and creative industries are influenced by the national strategy, geopolitics, culture, ideology, economy, policy, industrial structure, population and science and technology. More and more multi-national corporations all over the world carry out worldwide economic activities, such as HP business are available in 178 countries. With this 24-hour uninterrupted work system, this global cooperation improves work efficiency. Through economic activities, such as production, commodity, advertising, agents and agencies, multinational companies bring about the penetration of ideology of their home countries to other countries which will influence the production structure, consumer's values, life style, etc.. For instance, some young people formed the values of continuous consumption or even the value of excessive consumption. They tend to enjoy comfort, and some of them become boomerang kids who live off their parents. More and more people measure a person's ability and achievements through one's financial status, thus forming the value of solely paying attention to money. These value concepts also affect creative talents. Under relatively good social environment, this influence will be weakened to some extent. But if under bad social environment, social contradictions will exacerbate this effect, creative talents will feel threatened by various restrictions. They will not play their roles and cannot feel the value of existence. They will be in a state of total ignorance, resulting in a vicious circle for creative talents are disseminators. 
2) The impact of talents going global on the value of the creative talents

Because of the continuous development of modern network technology and economic globalization, people will compete and cooperate with each other around the world. Carlotta Perez, a Venezuelan expert whose main field of research is on the relationship between science and technology and social and economic development argues that the more complex the global network is, the more the company wants to cooperate and strengthen management in research and design, global markets, data sharing and security. Carlotta Perez, an expert on Venezuela's research and social and economic development, said: the more complex the global network is, the more it wants to cooperate and strengthen management in research and design, global markets, data sharing and security. Creative talents need to have ability to cooperate. In this team composed by multicultural talents, the free values will enable the creative talents from different countries, different cultures with different thinking abilities to freely discuss and exchange ideas, to help different parties to cooperate, so that the target can be successfully completed. Without freedom, it is difficult to display the creativity of these talents, so as to reduce the sense of achievement and social belongings of creative talents. In addition, equal values provide people with equal opportunity to succeed. All kinds of social contradictions and hierarchical social system are a limit to the equal value. At the same time, if a country provides sufficient resources, more growth and development space for creative talents, they will play a greater role in the development of the country.

3) The influence of cultural globalization on the value of creative talents

From the movies that were on In 2012 in China: The Viral Factor, Battleship, Mission Impossible 4, the Bourne Identity, Lost On Journey - Lost in Thailand and so on, it is not difficult to find that all those movies show local customs, practices and cooperation of several countries and different regions. The global cooperation in movie making and screening is a good way to promote the cultural exchange and integration, and thus reduce cultural differences. The cultural cohesion is conducive to the maintenance of world peace and harmony. The movie, as well as television, newspapers, books, networks, games, animation and plays a role in educating the people in their development and has a subtle influence on people's political orientation, value orientation and lifestyle. With the cultural globalization, the diversity and complexity of the culture is more obvious. Through the multi-national corporations, the country can convey its ideology to other countries so that it is hard to identify the value of other country's culture, beliefs and ideas, not to mention to check whether other cultures will be compatible with the home culture. The values of cultural and creative talents might be the combination of multinational values. They are inclined to accept the cultures rising in response to the high-tech, more entertainment, going -beyond-the-reality imagination. Many people advocate the values for quick success and they don't trust public security system. Values that honesty, integrity and fair trade will lead to success were given up. Because of all these, people may not work hard or work in a more strict way, the risk level of the society will increase.

4) The influence of science and technology on Creative

Talents

Science and technology is a double-edged sword, it can greatly promote the work efficiency of creative talents, such as the application of various software to design and communication, cloud technology, micro manufacturing, micro design, four-dimensional printing, industry 4.0 etc.. But it has also brought a huge human rights problem ---- creative talent's thinking and creativity has been a huge obstacle, just like what we have seen from the movie Avatar. Because of the disadvantageous effect of this technology, each country will be faced with the situation that they cannot receive all talents and encourage the free airing of views. Thus will have a negative effect on the beliefs, values, and power of spreading the national culture.

\section{B. The impact of international relations and domestic politics on the values of the creative talents}

In Gullah Albion's opinion, the international system has two key forces: first, a distribution state of national political power; second, the distribution of the economic activities and wealth[6].Good international relations show that political power distribution between countries is rational. The rational distribution of economic activities and wealth in the international economy can promote common prosperity and obtain a win-win situation. Meanwhile common prosperity brings the power of culture and creative talents to full play. This will also affect the way how and how much the country's wealth accumulates as well as social cohesion.

Many conflicts arise because of competition for resources and energy so that international relations become more complex. The international economy becomes more complex and unconventional, all kinds of energy and resource consumption are further intensified, and the ecological environment has become worse. Values have undergone new changes, such as patriotism, nationalism, ecologism, pacifism, saving principle etc.. The increasing complexity and risk of international relations will make modern technology the greatest threat for creative talents. With the development of the technology and extreme technological means talents will likely disappear. The values of creative talents will show its counterbalance with modern technology, the higher the talents are, the more evident the power will be. Social contradictions become more obvious and management more muddled. At a result, human rights will become particularly important. Influenced by the international relations, domestic politics will experience great changes which will gather together those creative talents naturally. Under the new international relations, the emergence of new type of domestic politics and new ideology, namely the mainstream ideology will serve the people better. 


\section{Ideology of cultural and creative talents in response to the global development}

Ideology is still very important for the country which can unify the people's beliefs and ideas to resolve the contradictions in the society and to maintain the country's development and stability. Cultural and creative talents act as a bridge between the country and the people. They encourage mutual dependence, tolerance, opening to the outside world, elimination of doubts and dissatisfaction, creating valuable cultural products, showing excellent local culture, absorbing and inclusion of some outstanding foreign culture, the communication of national thoughts, promoting human civilization which will enable people to share the results, to build the country, and to live and work in peace and contentment. The core values of cultural and creative talents are that they have the freedom to act and think in the future for better thinking and creation. Cultural and creative talents should possess the following values, such as hard work, learning knowledge, enthusiasm, optimism, loyalty, faith, positive attitude to life, good moral concern, ecological awareness, saving consciousness, patriotism and the control of the material desires. Cultural and creative talents themselves, as a part of the middle class[7], have good professional knowledge and professional skills, they have a sound financial footing, they should be given an equal opportunity for development, and free and relaxed environment, but they should not be given absolute freedom. These are beneficial to the quicker and better formation of the national ideology of cultural and creative talents and the communication.

\section{Conclusion}

This paper analyzes the role and characteristics of creative talents, the relationship between ideology, values and culture, and the factors influencing the values of creative talents including economic, talents' and cultural globalization, science and technology, international relations and domestic politics. The paper puts forward the mainstream values of the creative talents. Creative talents with a good national ideology can create cultural products that can spread the national ideology to the mass. They can concentrate the strength and the forces of the mass and thus promote the domestic political progress and social stability.

\section{Acknowledgment}

The studio's research projects: Ideology of cultural and creative talents in response to the global development and the construction of the democratic network platform and thanks for members of studio and other supported collaborators.

\section{References}

[1] Thomas L. Friedman, The world is flat, Hunan Science \&Technology Press, pp. 1-181,2011.

[2] Jacques Attali, A brief history of the future, Shanghai Academy of Social Science Press, pp. 67,2010.

[3] Yu Sinian, Weiming, Cultural evolution for strategy of contemporary China, China Renmin University Press, pp. 102-118,2010.

[4] Liu Xuetao, Li Daisong, Zhangge, Capital standardization: cultural and creative industries, Science Press, pp. 25-31,2010.

[5] David Popenoe, Sociology, China Renmin University Press, pp. 93-96, 2011.

[6] Robert O. Keohane, Hailen V. Milner, Internationalization and domestic politics, Peking University Press, pp. 1-19,2005.

[7] Lang Xianping, Sunjin, The China economy is on the utmost dangerous edges, Dongfang Press, pp. 68-110,2012. 